\title{
An Efflux Pumps Inhibitor Significantly Improved the Antibacterial Activity of Botanicals from Plectranthus glandulosus towards MDR Phenotypes
}

\author{
Gravalain Nanmeni, ${ }^{1,2}$ Alex T. Tedonkeu, ${ }^{3}$ Aimé G. Fankam $\mathbb{D}^{1},{ }^{1}$ Armelle T. Mbaveng ${ }^{1 D},{ }^{1}$ \\ Brice E. N. Wamba, ${ }^{1}$ Paul Nayim, ${ }^{1}$ Gabin T. M. Bitchagno, ${ }^{3}$ Raïssa T. Nzogong, ${ }^{3}$ \\ Maurice D. Awouafack, ${ }^{3}$ Mathieu Tene, ${ }^{3}$ Veronique P. Beng, ${ }^{2}$ and Victor Kuete ${ }^{1}{ }^{1}$ \\ ${ }^{1}$ Department of Biochemistry, Faculty of Science, University of Dschang, Dschang, Cameroon \\ ${ }^{2}$ Department of Biochemistry, Faculty of Science, University of Yaoundé I, Yaoundé, Cameroon \\ ${ }^{3}$ Department of Chemistry, Faculty of Science, University of Dschang, Dschang, Cameroon \\ Correspondence should be addressed to Victor Kuete; kuetevictor@yahoo.fr
}

Received 25 January 2021; Accepted 4 May 2021; Published 11 May 2021

Academic Editor: Jesus L. Romalde

Copyright @ 2021 Gravalain Nanmeni et al. This is an open access article distributed under the Creative Commons Attribution License, which permits unrestricted use, distribution, and reproduction in any medium, provided the original work is properly cited.

\begin{abstract}
Bacterial multidrug resistance causes many therapeutic failures, making it more difficult to fight against bacterial diseases. This study aimed to investigate the antibacterial activity of extract, fractions, and phytochemicals from Plectranthus glandulosus (Lamiaceae) against multidrug-resistant (MDR) Gram-negative phenotypes expressing efflux pumps. The crude extract after extraction was subjected to column chromatography, and the structures of the isolated compounds were determined using spectrometric and spectroscopic techniques. Antibacterial assays of samples alone and in the presence of an efflux pump inhibitor (phenylalanine-arginine $\beta$-naphthylamide, $\mathrm{PA} \beta \mathrm{N}$ ) were carried out using the broth microdilution method. The phytochemical study of $P$. glandulosus plant extract afforded seven major fractions (A-G) which lead to the isolation of seventeen known compounds. The ethanol extract of $P$. glandulosus was not active at up to $1024 \mu \mathrm{g} / \mathrm{mL}$, whereas its fractions showed MICs varying from 32 to $512 \mu \mathrm{g} / \mathrm{mL}$ on the studied bacteria. Fraction C of P. glandulosus showed the lowest MIC (32 $\mu \mathrm{g} / \mathrm{mL})$ on E. coli ATCC8739 strain. Fraction D presented the highest activity spectrum by inhibiting the growth of 90\% (9/10) of the studied bacteria. The presence of PA $\beta \mathrm{N}$ has improved the activity of extract and all fractions. Overall, the tested phytochemicals showed low activity against the studied bacteria. The overall results obtained in this study show that some fractions from P. glandulosus, mainly fractions $\mathrm{C}$ and $\mathrm{D}$, should be investigated more for their possible use to fight against MDR bacteria.
\end{abstract}

\section{Introduction}

Among infectious diseases, those due to pathogenic bacteria are becoming more worrying. According to the $\mathrm{WHO}$, they are responsible for more than 560,000 deaths or about a fifth of the 2.7 million neonatal deaths per year [1]. Antibiotics, also known as antimicrobial drugs, are drugs used for treating infections caused by bacteria. They have transformed medicine and saved millions of lives [2-4]. Therefore, misuse and overuse of these drugs have contributed to a phenomenon known as antibiotic resistance, which is developed when potentially harmful bacteria change in a way that reduces or eliminates the effectiveness of antibiotics $[5,6]$. The consequences of that phenomenon include an increase of hospital stay, the cost of care, as well as the mortality rate [5]. The multidrug resistance observed in Gram-negative bacteria is mainly attributed to the overexpression of efflux pumps via resistance-nodulation cell division (RND) pumps [7]. The fact that bacterial infections can no longer be treated with antibiotics depicts an unknown future in healthcare [8]. To respond to the current challenges of discovering novel antibiotics, it is important to 
direct research towards new substances. In accordance with this, previous studies have shown that plants are sources of antimicrobial substances and therefore could be as an alternative to fight against infections due to MDR bacteria $[4,9-16]$.

Plectranthus glandulosus Hook. F. (Lamiaceae) is an evergreen perennial flowering herbal plant, highly branched herb up to 3 meters tall, widely distributed in West, Central, and South Africa $[17,18]$. It is used in Cameroon's traditional medicine to treat dermatitis, bellyache, venereal diseases, internal inflammation, lower abdominal, and nerve ache $[17,19]$. Known as Ava in "Ewondo," a local tongue in Cameroon, the plant is used as a spice in this part of the country [17]. Some compounds including one methoxylated flavonoid derivative, plectranmicin, and one monoterpene derivative, plectranmicinol, together with seven known compounds including 5-hydroxy-3,7,2',4'tetramethoxyfla vone; 5,7-dihydroxy-3,2', $4^{\prime}$-trimethoxyflavone; 7-hydroxy5,6,4'-trimethoxyflavone; 3-epi-betulinic acid; $3-O-\beta$-Dglucopyranosyl; stigmasterol; $\beta$-sitosterol, and 4 -epi-fridelin were isolated from the whole plant of the studies species [20]. Earlier biological studies reported the antinociceptive and anti-inflammatory effects [21] as well as the antioxidant and insecticidal activities of $P$. glandulosus [22, 23].

To contribute to the search for new antibacterial substances, we set out, in this study, to investigate the antibacterial activity of extract, fractions, and isolated compounds from Plectranthus glandulosus (Lamiaceae) against MDR Gram-negative phenotypes expressing efflux pumps.

\section{Materials and Methods}

2.1. Plant Collection and Extraction. The whole plant of Plectranthus glandulosus was collected in Dschang, West Region of Cameroon, in January 2017. Authentication was performed by Mr. Fulbert Tadjouteu, a botanist of the Cameroon National Herbarium in Yaoundé, where our sample was deposited under the voucher number 49084/ HNC. The dried and powdered plant material $(3.5 \mathrm{~kg})$ was extracted three times ( $72 \mathrm{~h}$ each time) by maceration in EtOH $(15 \mathrm{~L})$ at room temperature to afford a crude extract (234 g, 6.7\% yield) after filtration, and removal of the solvent was carried out using a rotary evaporator. A portion $(224.0 \mathrm{~g})$ of this extract was subjected to silica gel column chromatography (CC) eluting with a mixture of petroleum ether/ethyl acetate (EtOAc) followed by EtOAc/MeOH in increasing polarity. 125 fractions of $400 \mathrm{~mL}$ each were collected and combined into six major fractions based on their TLC profiles to afford seven major fractions (A-G).

2.2. General Experimental Procedures. MS data were measured on the JEOL MS Station JMS-700 spectrometer or JEOL $600 \mathrm{MS}$ Route spectrometer. High-resolution mass spectra were recorded on a Micromass-Q-TOF-Ultima-3mass spectrometer (Waters) with lockspray interface and a suitable external calibrant. NMR spectra were recorded on a Bruker Avance III ( ${ }^{1} \mathrm{H}-\mathrm{NMR}: 600 \mathrm{MHz}$ and ${ }^{13} \mathrm{C}-\mathrm{NMR}$ :
151.1 MHz), JEOL spectrometers ( ${ }^{1} \mathrm{H}-\mathrm{NMR}: 500 \mathrm{MHz}$ and ${ }^{13} \mathrm{C}-\mathrm{NMR} 125 \mathrm{MHz}$ ), or a Bruker Avance AV-400spectrometer ( ${ }^{1} \mathrm{H}-\mathrm{NMR}$ : $400 \mathrm{MHz}$ and $\left.{ }^{13} \mathrm{C}-\mathrm{NMR} 100 \mathrm{MHz}\right)$. The chemical shifts were reported in parts per million (ppm) with TMS as internal standard. Deuterated solvents, methanol $\left(\mathrm{CD}_{3} \mathrm{OD}\right)$, dimethyl sulfoxide $\left(\mathrm{DMSO}-\mathrm{d}_{6}\right)$, pyridine $\left(\mathrm{C}_{5} \mathrm{D}_{5} \mathrm{~N}\right)$, and chloroform $\left(\mathrm{CDCl}_{3}\right)$ were used as solvents for the NMR experiments. $\mathrm{CC}$ was performed with silica gel 60 F254 (70-230 mesh; Merck) and gel permeation with Sephadex LH-20 gel. TLC was carried out with precoated silica gel Kieselgel 60 F254 plates ( $0.25 \mathrm{~mm}$ thick), and spots were detected with UV light (254 and $366 \mathrm{~nm}$ ) and further sprayed with $20 \% \mathrm{H}_{2} \mathrm{SO}_{4}$ reagent followed by heating at $100^{\circ} \mathrm{C}$.

2.3. Isolation of Constituents. Fraction A (27.0 g) contained mostly fatty material and was not further investigated. Fraction B ( $46.0 \mathrm{~g}$ ) was subjected to CC over silica gel eluted with petroleum ether/EtOAc in increasing polarity to give a mixture of $\beta$-sitosterol and stigmasterol (1 and 2, $30.0 \mathrm{mg}$ ). Fraction C (22.0 g) was also subjected to CC over silica gel and eluted with a gradient of $n$-hexane/EtOAc followed by EtOAc/MeOH. 77 fractions of $100 \mathrm{~mL}$ each were collected and combined based on their analytical TLC profiles into three main subfractions tagged C1-C3. Subfraction C1 crystallized in hexane/EtOAc (6:4) to yield oleanolic acid (3, $3.5 \mathrm{mg}$ ). Subfraction C3 was further purified on silica gel eluting with $n$-hexane/EtOAc of increasing polarity to afford pilloin $(4,5.0 \mathrm{mg})$. Fraction D $(18.0 \mathrm{~g})$ was subjected to silica gel CC eluting with a gradient of petroleum ether/EtOAc. 110 fractions of $75 \mathrm{~mL}$ each were collected and grouped based on their analytical TLC analysis into 5 subfractions (D1-D5). Subfraction D1 was filtered and washed with EtOAc to give chrysoeriol $(6,18.0 \mathrm{mg})$. D2 was further subjected to silica gel CC using a gradient of petroleum ether/EtOAc to afford luteolin-7-methyl ether (7, $8.0 \mathrm{mg})$. D3 was subjected to silica gel CC eluting with the isocratic system $n$-hexane-EtOAc $(85: 15)$ to afford 5-hydroxy-7, $4^{\prime}$ dimethoxyflavone $(8,5.5 \mathrm{mg})$. The purification of subfraction D5 using isocratic system petroleum ether/EtOAc $(1: 1)$ afforded a mixture of maslinic acid and benthamic acid $(9+10,6.0 \mathrm{mg})$. D4 was subjected to silica gel CC eluted with a gradient of $n$-hexane/EtOAc to give 5,6-dihydroxy-7,3', $4^{\prime}$ trimethoxyflavone $(11,26.0 \mathrm{mg})$ and ladanein $(12,31.0 \mathrm{mg})$. Similarly, elution of fraction $E(14.5 \mathrm{~g})$ using $n$-hexane/ EtOAc followed by EtOAc/MeOH of increasing polarities yielded four subfractions indexed from E1 to E4. E2 was subjected to silica gel CC eluted with a gradient of $n$-hexane/ EtOAc to afford three further subfractions (E2-1 to E2-3). The E2-3 subfraction crystallized to give hederagenin (13, $5.5 \mathrm{mg})$. Filtration of E3, washed with $\mathrm{MeOH}$ yielded cylicodiscic acid (14, $4.5 \mathrm{mg})$. Silica gel CC of fraction F (11.5 g) using $\mathrm{CH}_{2} \mathrm{Cl}_{2}-\mathrm{MeOH}$ in increasing polarities afforded sitosterol 3-O- $\beta$-D-glucopyranoside $(5,7.5 \mathrm{mg})$. Fraction $\mathrm{G}$ $(23.5 \mathrm{~g})$ was also subjected to silica gel CC eluted with a gradient of EtOAc/MeOH to afford six subfractions G1-G6. G1 crystallized at room temperature to afford a mixture of chrysoeriol 5-O- $\beta$-D-glucopyranoside and luteolin-7-O- 
methyl-5-O- $\beta$-D-glucopyranoside $(15+16,22.5 \mathrm{mg})$. Similarly, subfraction G2 crystallized to afford galuteolin (17, $20.5 \mathrm{mg}$ ).

\subsection{Antibacterial Assay}

2.4.1. Chemicals. The pure antibiotic chloramphenicol $(\mathrm{CHL}) \geq 98 \%$ was used as reference antibacterial (RA). $p$ Iodonitrotetrazolium chloride (INT) $0.2 \%$ and phenylalanine-arginine $\beta$-naphthylamide $(\mathrm{PA} \beta \mathrm{N}) \geq 97 \%$ were used as microbial growth indicator and efflux pump inhibitor (EPI), respectively. All these chemicals were provided from SigmaAldrich, St. Quentin Fallavier, France. Dimethylsulfoxide (DMSO) $2.5 \%$ at the final concentration was used to dissolve the tested samples.

2.4.2. Bacteria Strains and Culture Media and Growth Conditions. A panel of 10 strains belonging to Gram-negative bacteria was used in the study. They included MDR isolates (laboratory collection) and reference strains of Escherichia coli (ATCC8739 and AG102), Enterobacter aerogenes (ATCC13048 and EA27), Klebsiella pneumoniae (ATCC11296 and KP55), Providencia stuartii (ATCC 29916 and PS2636), and Pseudomonas aeruginosa (PA01 and PA124). The clinical strains were obtained from the laboratory collection from UMR-MD1, University of Marseille, France. The bacterial features are reported in Table S1 (Supplementary Material S1). The bacteria were maintained at $4^{\circ} \mathrm{C}$ and subcultured overnight on a fresh Mueller-Hinton agar (MHA) before any antibacterial assay.

2.4.3. Bacterial Susceptibility Determination. The antibacterial activity of the extract, fractions, and isolated compounds was determined using INT colorimetric assay [24] with some modifications as previously described [25]. Briefly, samples were dissolved in 10\% dimethyl sulfoxide (DMSO)/Mueller-Hinton Broth (MHB) and serially diluted two-fold (in a 96-well microplate). Then, $100 \mu \mathrm{L}$ of inoculum $\left(2 \times 10^{6} \mathrm{CFU} / \mathrm{mL}\right)$ prepared in MHB was added in each well. Chloramphenicol was used as RA, and the well containing the vehicle (DMSO 2.5\%) was used as control. The plates were then covered with a sterile plate sealer and gently shaken to mix the contents of the wells. The microplates were incubated at $37^{\circ} \mathrm{C}$ for $18 \mathrm{~h}$. The minimal bactericidal concentration (MIC) of each sample, defined as the lowest sample concentration that inhibited complete bacteria growth, was detected following the addition of $40 \mu \mathrm{L}$ INT $(0.2 \mathrm{mg} / \mathrm{mL})$ and incubation at $37^{\circ} \mathrm{C}$ for $30 \mathrm{~min}$. For the minimal bactericidal concentrations (MBCs) determination, a volume of $150 \mu \mathrm{L}$ of MHB was introduced in a new 96-well microplate, following addition of $50 \mu \mathrm{L}$ of the previous well microplate contents where no microbial growth was observed and which did not receive an INT (during the reading of MICs). After $48 \mathrm{~h}$ incubation at $37^{\circ} \mathrm{C}$, the $\mathrm{MBC}$ of each sample was determined and defined by adding $40 \mu \mathrm{L}$ of $0.2 \mathrm{mg} / \mathrm{mL}$ INT as described above. Crude extract as well as the active fractions ( $C$ and $\mathrm{D}$ ) were also tested alone and then in the presence of $\mathrm{PA} \beta \mathrm{N}$, an efflux pump inhibitor (EPI), at $30 \mu \mathrm{g} / \mathrm{mL}$ final concentration. In this last case, the activity modulation factors (AMFs) were determined by a ratio of MIC sample alone/MIC sample $+\mathrm{PA} \beta \mathrm{N}$ combination [16]. Each treatment experiment was performed in triplicate, and the assay was repeated thrice.

\section{Results}

3.1. Phytochemistry. The EtOH extract of P. glandulosus was investigated over silica gel and Sephadex LH-20 column chromatography leading to seventeen compounds. Their structures were determined by spectroscopic techniques and comparison of recorded data with those of similar compounds in the literature (Figure 1). They included the mixture of stigmasterol and $\beta$-sitosterol $(1+2)$ [26], oleanolic acid (3) [27], pilloin (4) [28], $\beta$-sitosterol 3-O- $\beta$-Dglucopyranoside (5) [29], chrysoeriol (6) [30], luteolin 7methyl ether (7) [31], 5-hydroxy-7,4'-dimethoxyflavone (8) [32], mixture of maslinic acid (9) [33] and benthamic acid (10) [34], 5,6-dihydroxy-7, $3^{\prime}, 4^{\prime}$-trimethoxyflavone (11) [35], ladanein (12) [36], hederagenin (13) [37], cylicodiscic acid (14) [38], mixture of chrysoeriol 5-O- $\beta$-D-glucopyranoside (15) [39] and 7-O-methyl luteolin 5-O- $\beta$-D-glucopyranoside (16) [40], and galuteolin (17) [41]. All ${ }^{1} \mathrm{H}$ and ${ }^{13} \mathrm{C}-\mathrm{NMR}$ spectra and major chemical shifts of these compounds are listed in the Supplementary Materials (S2).

3.2. Antibacterial Activity of Extract, Fractions, and Compounds. The antibacterial activity of extract, fractions and isolated compounds, and CHL was evaluated against 10 Gram-negative bacteria including reference strains and multidrug-resistant clinical isolates. Tables 1-3 present all these results. Bactericidal or bacteriostatic effects of each sample on a bacterial strain were shown by calculating the $\mathrm{MBC} / \mathrm{MIC}$ ratio. The EtOH extract of $P$. glandulosus was not active at up to $1024 \mu \mathrm{g} / \mathrm{mL}$, whereas its fractions showed MICs varying from 32 to $512 \mu \mathrm{g} / \mathrm{mL}$ on the studied bacteria. Fraction C of P. glandulosus showed the lowest MIC ( $32 \mu \mathrm{g} /$ $\mathrm{mL}$ ) on E. coli ATCC8739 strain. Fraction D presented the highest activity spectrum by inhibiting the growth of $90 \%$ ( $9 /$ 10) of the studied bacteria, whereas fractions $\mathrm{F}-\mathrm{H}$ were not active on the tested bacteria at up to $512 \mu \mathrm{g} / \mathrm{mL}$. The study showed that all the isolated compounds were generally less active than their main fractions (Table 2) with MICs ranging from 64 to $512 \mu \mathrm{g} / \mathrm{mL}$. The most active compound, chrysoeriol (6) isolated from the most active fraction, fraction $\mathrm{D}$, showed MICs ranging from 64 to $256 \mu \mathrm{g} / \mathrm{mL}$ against $30 \%$ (3/ 10 ) of strains (E. coli AG102, K. pneumoniae ATCC11296, and $P$. stuartii PS2636). Chloramphenicol was active against $100 \%(10 / 10)$ of bacteria with MICs ranging from 2 to $64 \mu \mathrm{g} /$ $\mathrm{mL}$ (Table 1). Except with fraction $\mathrm{F}$, which displayed $\mathrm{MBC}=512 \mu \mathrm{g} / \mathrm{mL}$ against $E$. aerogenes $\mathrm{EA} 27$, the other tested plant samples showed no MBC up to $512 \mu \mathrm{g} / \mathrm{mL}$. However, MBC/MIC ratio of chloramphenicol showed that it has bactericidal effects on most of the tested bacteria (Tables 1 and 2). Fraction $\mathrm{F}$ also presented the bactericidal effect against E. aerogenes EA 27 (MBC/MIC $\leq 4)$. 
<smiles>CCC(CC[C@@H](C)C1CCC2C3CC=C4C[C@@H](O)CC[C@]4(C)C3CC[C@@]21C)C(C)C</smiles>

1<smiles>[R]c1ccc(-c2cc(=O)c3c([R])c([R])c([R])cc3o2)cc1[R]</smiles><smiles>CCC(/C=C/[C@H](C)C1CCC2C3CC=C4C[C@@H](O)CC[C@]4(C)C3CC[C@@]21C)C(C)C</smiles>

2

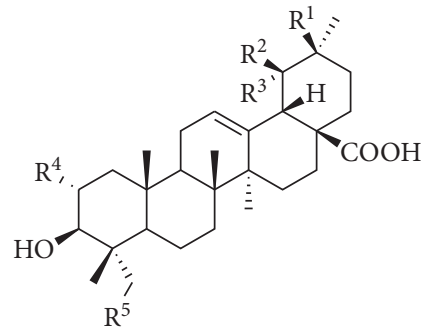

$\begin{array}{llllll} & \mathrm{R}^{1} & \mathrm{R}^{2} & \mathrm{R}^{3} & \mathrm{R}^{4} & \mathrm{R}^{5} \\ 3 & \mathrm{Me} & \mathrm{H} & \mathrm{H} & \mathrm{H} & \mathrm{H} \\ 9 & \mathrm{Me} & \mathrm{H} & \mathrm{H} & \mathrm{OH} & \mathrm{H} \\ 10 & \mathrm{H} & \mathrm{Me} & \mathrm{OH} & \mathrm{H} & \mathrm{H} \\ 13 & \mathrm{Me} & \mathrm{H} & \mathrm{H} & \mathrm{H} & \mathrm{OH}\end{array}$

$\begin{array}{llllll} & \mathrm{R}^{1} & \mathrm{R}^{2} & \mathrm{R}^{3} & \mathrm{R}^{4} & \mathrm{R}^{5} \\ 4 & \mathrm{OMe} & \mathrm{H} & \mathrm{OH} & \mathrm{OMe} & \mathrm{OH} \\ 6 & \mathrm{OH} & \mathrm{H} & \mathrm{OMe} & \mathrm{OH} & \mathrm{OH} \\ 7 & \mathrm{OMe} & \mathrm{H} & \mathrm{OH} & \mathrm{OH} & \mathrm{OH} \\ 8 & \mathrm{OMe} & \mathrm{H} & \mathrm{H} & \mathrm{OMe} & \mathrm{OH} \\ 11 & \mathrm{OMe} & \mathrm{OH} & \mathrm{OMe} & \mathrm{OMe} & \mathrm{OH} \\ 12 & \mathrm{OMe} & \mathrm{OH} & \mathrm{H} & \mathrm{OMe} & \mathrm{OH} \\ 15 & \mathrm{OH} & \mathrm{H} & \mathrm{OH} & \mathrm{OMe} & \mathrm{Glu} \\ 16 & \mathrm{OMe} & \mathrm{H} & \mathrm{OH} & \mathrm{OH} & \mathrm{Glu} \\ 17 & \mathrm{OH} & \mathrm{H} & \mathrm{OH} & \mathrm{OH} & \mathrm{Glu}\end{array}$

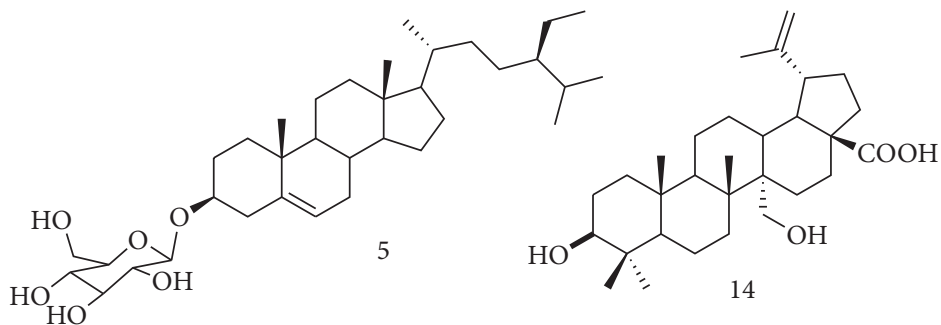

FIGURE 1: Structures of isolated compounds 1-17.

TABLE 1: Minimum inhibitory concentration (MIC) and minimum bactericidal concentration (MBC) in $\mu \mathrm{g} / \mathrm{mL}$ of crude extracts and fractions from $P$. glandulosus and chloramphenicol against selected Gram-negative bacteria.

\begin{tabular}{|c|c|c|c|c|c|c|c|c|c|}
\hline \multirow[b]{2}{*}{ Bacteria } & \multicolumn{9}{|c|}{ Tested samples, MICs (MBCs) in $\mu \mathrm{g} / \mathrm{mL}$} \\
\hline & Extract & Fraction B & Fraction $\mathrm{C}$ & $\begin{array}{c}\text { Fraction } \\
\text { D }\end{array}$ & Fraction E & Fraction $\mathrm{F}$ & $\begin{array}{c}\text { Fraction } \\
\text { G }\end{array}$ & $\begin{array}{c}\text { Fraction } \\
\mathrm{H}\end{array}$ & Chloramphenicol \\
\hline \multicolumn{10}{|l|}{ Escherichia coli } \\
\hline ATCC 8739 & - & $512(>512)$ & $32(>512)$ & $64(>512)$ & $>512$ & $>512$ & $>512$ & $>512$ & $2(64)$ \\
\hline AG 102 & - & $512(>512)$ & $\begin{array}{c}256 \\
(>512)\end{array}$ & $256(>512)$ & $512(>512)$ & $>512)$ & $>512$ & $>512$ & $32(256)$ \\
\hline \multicolumn{10}{|c|}{ Enterobacter aerogenes } \\
\hline ATCC 13048 & - & $512(>512)$ & $\begin{array}{c}128 \\
(>512)\end{array}$ & $512(>512)$ & $512(>512)$ & $>512$ & $>512$ & $>512$ & $32(128)$ \\
\hline EA 27 & - & $>512$ & $\begin{array}{c}256 \\
(>512)\end{array}$ & $512(>512)$ & $>512$ & $512(512)$ & $>512$ & $>512$ & $16(256)$ \\
\hline \multicolumn{10}{|c|}{ Klebsiella pneumoniae } \\
\hline ATCC 11296 & - & $512(>512)$ & $\begin{array}{c}256 \\
(>512)\end{array}$ & $512(>512)$ & $512(>512)$ & $>512$ & $>512$ & $>512$ & $8(256)$ \\
\hline KP 55 & - & $>512$ & $64(>512)$ & $512(>512)$ & $512(>512)$ & $>512$ & $>512$ & $>512$ & $32(256)$ \\
\hline \multicolumn{10}{|c|}{ Providencia stuartii } \\
\hline ATCC 29916 & - & $>512$ & $>512$ & $512(>512)$ & $512(>512)$ & $512(>512)$ & $>512$ & $>512$ & $64(256)$ \\
\hline PS 2636 & - & $\begin{array}{c}256 \\
(>512)\end{array}$ & $\begin{array}{c}256 \\
(>512)\end{array}$ & $512(>512)$ & $512(>512)$ & $>512$ & $>512$ & $>512$ & $64(256)$ \\
\hline \multicolumn{10}{|l|}{$\begin{array}{l}\text { Pseudomonas } \\
\text { aeruginosa }\end{array}$} \\
\hline PA 01 & - & $\begin{array}{c}256 \\
(>512)\end{array}$ & $>512$ & $>512$ & $512(>512)$ & $>512$ & $>512$ & $>512$ & $64(>256)$ \\
\hline PA 124 & - & $\begin{array}{c}256 \\
(>512)\end{array}$ & $\begin{array}{c}256 \\
(>512)\end{array}$ & $512(>512)$ & $512(>512)$ & $>512$ & $>512$ & $>512$ & $64(>256)$ \\
\hline
\end{tabular}

$(-): \geq 1024 \mu \mathrm{g} / \mathrm{mL}$; MIC, minimum inhibitory concentration; MBC, minimum bactericidal concentration. 
TABLE 2: Minimum inhibitory concentration (MIC) and minimum bactericidal concentration (MBC) in $\mu \mathrm{g} / \mathrm{mL}$ of isolated compounds of P. glandulosus against selected Gram-negative bacteria.

\begin{tabular}{|c|c|c|c|c|c|}
\hline \multirow{2}{*}{ Bacteria } & \multicolumn{5}{|c|}{ Compounds, MICs (MBCs) in $\mu \mathrm{g} / \mathrm{mL}$} \\
\hline & 6 & 11 & 12 & $15+16$ & 17 \\
\hline \multicolumn{6}{|l|}{ Escherichia coli } \\
\hline ATCC 8739 & - & - & - & - & - \\
\hline AG 102 & $128(-)$ & - & - & $64(-)$ & - \\
\hline \multicolumn{6}{|c|}{ Enterobacter aerogenes } \\
\hline ATCC 13048 & - & - & - & - & - \\
\hline EA 27 & - & - & - & - & - \\
\hline \multicolumn{6}{|c|}{ Klebsiella pneumoniae } \\
\hline ATCC 11296 & $256(-)$ & $64(-)$ & - & $64(-)$ & $64(-)$ \\
\hline KP 55 & - & - & - & - & - \\
\hline \multicolumn{6}{|c|}{ Providencia stuartii } \\
\hline ATCC 29916 & - & - & - & $256(-)$ & $512(-)$ \\
\hline PS 2636 & $64(-)$ & $256(-)$ & $64(-)$ & $512(-)$ & - \\
\hline \multicolumn{6}{|c|}{ Pseudomonas aeruginosa } \\
\hline PA 01 & - & - & - & - & - \\
\hline PA 124 & - & - & - & - & - \\
\hline
\end{tabular}

$(-): \geq 512 \mu \mathrm{g} / \mathrm{mL}$; MIC, minimum inhibitory concentration; MBC, minimum bactericidal concentration; 6 , chrysoeriol; $11,5,6$-dihydroxy-7,3' ${ }^{\prime} 4^{\prime}$-trimethoxyflavone; 12, ladanein; 15, chrysoeriol 5-O- $\beta$-D-glucopyranoside; 16, 7-O-methyl luteolin 5-O- $\beta$-D-glucopyranoside; 17, luteolin 5-O- $\beta$-Dglucopyranoside.

TABLE 3: MICs $(\mu \mathrm{g} / \mathrm{mL})$ of extract, active fractions of P. glandulosus and chloramphenicol in the presence of PA $\beta \mathrm{N}$.

\begin{tabular}{|c|c|c|c|c|}
\hline \multirow{2}{*}{ Bacteria } & \multicolumn{4}{|c|}{ Tested samples, MIC in the presence of PA $\beta \mathrm{N}$ (AMFs) $(\mu \mathrm{g} / \mathrm{mL})$} \\
\hline & Extract & Fraction $\mathrm{C}$ & Fraction D & Chloramphenicol \\
\hline \multicolumn{5}{|l|}{ Escherichia coli } \\
\hline ATCC 8739 & $<8$ (nd) & $<4(>8)$ & $<4(>16)$ & $<2$ (nd) \\
\hline AG 102 & $<8$ (nd) & $8(32)$ & $<4(>64)$ & $8(4)$ \\
\hline \multicolumn{5}{|c|}{ Enterobacter aerogenes } \\
\hline ATCC 13048 & 32 (nd) & $64(2)$ & $256(2)$ & $32(1)$ \\
\hline EA 27 & $<8$ (nd) & $<4(>64)$ & $32(16)$ & $16(1)$ \\
\hline \multicolumn{5}{|c|}{ Klebsiella pneumoniae } \\
\hline ATCC 11296 & $<8$ (nd) & $<4(>64)$ & $<4(128)$ & $8(1)$ \\
\hline KP 55 & 32 (nd) & $32(2)$ & $64(8)$ & $32(1)$ \\
\hline \multicolumn{5}{|c|}{ Providencia stuartii } \\
\hline ATCC 29916 & $<8$ (nd) & $64(4)$ & $256(2)$ & $8(8)$ \\
\hline PS 2636 & 512 (nd) & $<4(64)$ & $256(2)$ & $16(4)$ \\
\hline \multicolumn{5}{|c|}{ Pseudomonas aeruginosa } \\
\hline PA 01 & $<8$ (nd) & $>512$ (nd) & $>512$ (nd) & $8(8)$ \\
\hline PA 124 & 256 (nd) & $64(4)$ & $512(1)$ & $16(4)$ \\
\hline
\end{tabular}

MIC, minimum inhibitory concentration; nd, not determined. Activity modulation factors (AMFs) were determined to qualify the potentiation level of sample activity in the presence of EPI. All assays were performed in triplicate and repeated thrice. In bold are AMF $\geq 4$.

3.3. Minimal Inhibitory Concentrations of Samples in Association with $P A \beta N$. Fractions $\mathrm{C}$ and $\mathrm{D}$, which showed the best antibacterial activity, the EtOH crude extract, and RA were tested in the presence of $\mathrm{PA} \beta \mathrm{N}$, an efflux pumps inhibitor. The overall results (Table 3 ) showed that, once associated with PA $\beta \mathrm{N}(30 \mu \mathrm{g} / \mathrm{mL})$, the activity of all tested samples increased by almost $90 \%$ of studied bacteria with activity modulation factors (AMFs) ranging from 2 to 128 for crude extract and fractions and from 4 to 8 for the reference antibiotic, chloramphenicol. $\mathrm{PA} \beta \mathrm{N}$ mostly potentiated the activity of extract and fraction $\mathrm{C}(10 / 10,100 \%)$ than fraction D and CHL (Table 3). The enhancement of the activity was also well observed on $P$. aeruginosa PA124, a known multidrug-resistant bacterium with high expression level of RND type efflux pumps.

\section{Discussion}

Antimicrobial agents are essential in reducing the global burden of infectious diseases. Plants as an inexhaustible source of novel molecules have long been used in traditional medicine for the treatment of several diseases including bacterial infections. Moreover, many techniques for isolation, characterization, and pharmacological evaluation have led to an interest in plant secondary metabolites as a source of new drugs, which are potential antimicrobials [42-44]. 
Previous chemical studies of that plant resulted in the isolation of many compounds among which those belonging to the phytochemical classes such as flavonoids are known for their antimicrobial activities $[20,42]$. In this study, many other known phytochemical compounds have been isolated from P. glandulosus (Figure 1), and their antibacterial activities were evaluated.

According to the cutoff values indicating the antibacterial activity of an edible plant extract, its part or its fractions as proposed by Tamokou et al. [45], fractions B-E of $P$. glandulosus, and mainly fractions $\mathrm{C}$ and $\mathrm{D}$ presented significant activity $(100<\mathrm{MIC} \leq 512 \mu \mathrm{g} / \mathrm{mL})$ against the tested bacteria strains. Fraction $\mathrm{D}$ has the highest activity with MICs ranging from 64 to $512 \mu \mathrm{g} / \mathrm{mL}$ against $90 \%(9 / 10)$ of the studied bacteria (Table 1). Antibiotics and isolated compounds with $\mathrm{MIC} \leq 10 \mu \mathrm{g} / \mathrm{mL}, 10<\mathrm{MIC} \leq 100 \mu \mathrm{g} / \mathrm{mL}$, or $\mathrm{MIC}>100 \mu \mathrm{g} / \mathrm{mL}$ are considered to have strong, moderate, or weak activity, respectively [46]. Based on this scale, it is noticed that isolated compounds generally displayed low activity against the tested bacteria (MIC $>100 \mu \mathrm{g} / \mathrm{mL}$ ). By comparing the activity of the extract and fractions (Table 1), crude extract $(\mathrm{MIC}>1024 \mu \mathrm{g} / \mathrm{mL})$ was less active than their derived fractions mainly, fractions $\mathrm{C}$ and $\mathrm{D}$ (MICs ranging from 64 to $256 \mu \mathrm{g} / \mathrm{mL}$ ). This suggests that the extract may contain some phytochemicals with antagonistic effects which have been separated by fractionation. Furthermore, in comparing the antibacterial activities of the active fractions (fractions $\mathrm{C}$ and $\mathrm{D}$ ) with that of their respective isolated constituents, it appears that these fractions were more active than the isolated compounds. This insinuates that compounds in each fraction may act synergistically [42, 47]. To the best of our knowledge, this work investigates for the first time antibacterial activity of the extract of $P$. glandulosus. Therefore, Ngassoum et al. [48] revealed low activity of the essential oils of the leaves of P. glandulosus against E. coli, $P$. fluorescens, and S. aureus. This study shows that fractions of $P$. glandulosus could be used to fight infections involving MDR bacteria. Chrysoeriol (6), isolated in P. glandulosus, is a methoxylated flavone known for its great scientific interest because of its promising antimicrobial activities against various Gram-negative and Gram-positive bacteria [49]. Its presence in the fraction D may explain the significant antibacterial activity of that fraction.

The activity of tested extract, fractions, as well as chloramphenicol significantly increased in association with $\mathrm{PA} \beta \mathrm{N}$, an efflux pump inhibitor (Table 3). In fact, efflux pumps can be blocked by an efflux pump inhibitor, thereby restoring not only the intracellular concentration but also the activity of antibiotics and/or extracts or phytochemicals [50]. This justifies the role of $\mathrm{PA} \beta \mathrm{N}$ which inhibits or blocks efflux pumps maintaining high intracellular concentrations of antibacterial substances $[50,51]$. In the present work, the activity observed in the presence of PA $\beta \mathrm{N}$ may indicate that the active principle $(s)$ contained in the tested extracts and/or fractions may have been expelled in its absence. This inhibitor would therefore block the efflux pumps and cause an increase in the intracellular concentration of the active principle $(s)$ contained in the extracts. This activity therefore confirms that efflux is one of the main resistance mechanisms expressed by the bacteria tested as indicated in Table S1 (Supplementary Materials, SM1).

\section{Conclusion}

The results obtained herein indicate that fractions $C$ and $D$ of Plectranthus glandulosus have significant antibacterial activity. Furthermore, this work has shown that the activity of these fractions as well as that of the crude extract can be significantly enhanced in the presence of $P A \beta N$, an efflux pump inhibitor to overcome MDR bacteria expressing efflux pumps.

\section{Data Availability}

All data generated or analyzed during this study are included within this article.

\section{Conflicts of Interest}

The authors declare that they have no conflicts of interest.

\section{Authors' Contributions}

GN, ATT, BENW, and PN carried out the study; ATM, MT, VPB, and VK designed the experiments. ATT and AGF prepared the data and wrote the manuscript; GTMB, RTN, DMA, and MT contributed to structure elucidation; ATM and VK supervised the work and provided the facilities for antibacterial assays. All authors read and approved the final manuscript.

\section{Acknowledgments}

The authors are thankful to the Cameroon National Herbarium for identification of plants. Alexander von Humboldt Foundation Equipment grants 3.4-8151/Kuete (GA-Nr. 19014) to VK and 3.4-8151/18026 to ATM.

\section{Supplementary Materials}

Additional file. Docx: SM1. Table S1 showing the characteristics of the studied bacteria; SM2. ${ }^{1} \mathrm{H}$ and ${ }^{13} \mathrm{C}-\mathrm{NMR}$ and major chemical shifts of studied compounds. (Supplementary Materials)

\section{References}

[1] S. H. Factor, J. A. Schillinger, H. D. Kalter et al., "Diagnostic et prise en charge des enfants fiévreux à Dhaka (Bangladesh) suivant les directives OMS/UNICEF pour la prise en charge intégrée des maladies de l'enfant," Bulletin de l'Organisation mondiale de la santé: la revue internationale de santé publique: recueil d'articles, vol. 6, 2002.

[2] H. Lode, "Safety and tolerability of commonly prescribed oral antibiotics for the treatment of respiratory tract infections," The American Journal of Medicine, vol. 123, no. 4, pp. S26S38, 2010.

[3] C. L. Ventola, "The antibiotic resistance crisis: part 1: causes and threats," P \& T: A Peer-Reviewed Journal for Formulary Management, vol. 40, no. 4, pp. 277-283, 2015. 
[4] G. T. M. Bitchagno, V.-A. Nchiozem-Ngnitedem, N. T. Wandji, G. C. T. Noulala, S. A. T. Fobofou, and B. N. Lenta, "Plant derived compounds against microbial infections and cancers," in Natural Products-From Bioactive Molecules to Human Health, C. Danciu, Ed., Intech Open, London, UK, 2020.

[5] World Health Organization (WHO), Antibiotic Resistance, World Health Organization, Geneva, Switzerland, 2020, https://www.who.int/news-room/fact-sheets/detail/ antibiotic-resistance.

[6] Food and Drug Administration (FDA), Combating Antibiotic Resistance, Food and Drug Administration, Silver Spring, MD, USA, 2019, https://www.fda.gov/consumers/consumerupdates/combating-antibiotic-resistance.

[7] O. Lomovskaya and W. Watkins, "Inhibition of efflux pumps as a novel approach to combat drug resistance in bacteria," Journal of Molecular Microbiology and Biotechnology, vol. 3, no. 2, pp. 225-236, 2001.

[8] A. Chokshi, Z. Sifri, D. Cennimo, and H. Horng, "Global contributors to antibiotic resistance," Journal of Global Infectious Diseases, vol. 11, no. 1, pp. 36-42, 2019.

[9] V. Kuete, R. Metuno, B. Ngameni et al., "Antimicrobial activity of the methanolic extracts and compounds from Treculia obovoidea (Moraceae)," Journal of Ethnopharmacology, vol. 112, no. 3, pp. 531-536, 2007.

[10] J. K. Dzotam, F. K. Touani, and V. Kuete, "Antibacterial and antibiotic-modifying activities of three food plants (Xanthosoma mafaffa Lam., Moringa oleifera (L.) Schott and Passiflora edulis Sims) against multidrug-resistant (MDR) Gram-negative bacteria," BMC Complementary and Alternative Medicine, vol. 16, no. 9, 2016.

[11] H. Chandra, P. Bishnoi, A. Yadav, B. Patni, A. P. Mishra, and A. R. Nautiyal, "Antimicrobial resistance and the alternative resources with special emphasis on plant-based antimicrobials-A review," Plants, vol. 6, no. 2, p. 16, 2017.

[12] A. G. Fankam, J. R. Kuiate, and V. Kuete, "Antibacterial activities of Beilschmiedia obscura and six other Cameroonian medicinal plants against multi-drug resistant Gram-negative phenotypes," BMC Complementary and Alternative Medicine, vol. 14, 2014.

[13] C. F. Tchinda, I. K. Voukeng, V. P. Veronique, and V. Kuete, "Mechanisms of action of roots crude extract and adianthifolioside GS1 from Albizia adianthifolia (Fabaceae) against MDR Gram-negative enteric bacteria," Investigational Medicinal Chemistry and Pharmacology, vol. 3, no. 2, p. 13, 2020.

[14] E. B. N. Wamba, P. Nayim, T. A Mbaveng et al., "Syzigium jambos displayed antibacterial and Antibiotic-Modulation Activities against resistances phenotypes," Evidence-Based Complementary and Alternative Medicine, vol. 2018, no. 12, 12 pages, Article ID 5124735, 2018.

[15] M. G. F. Guefack, S. B. Tankeo, C. M. N. Ngaffo et al., "Antibiotic-potentiation activities of three animal species extracts, Bitis arietans, Helix aspersa, and Aristaeomorpha foliacea and mode of action against MDR Gram-negative bacteria phenotypes," Investigational Medicinal Chemistry and Pharmacology, vol. 4, no. 1, p. 15, 2021.

[16] C. M. N. Ngaffo, S. B. Tankeo, M. G. G. Fofack et al., "In vitro antibacterial and antibiotic-potentiation activities of five edible plant extracts and mode of action against several MDR Gram-negative phenotypes," Investigational Medicinal Chemistry and Pharmacology, vol. 4, no. 1, p. 14, 2021.

[17] J. Pele and S. Berre, "Aliment d'origine végétal au Cameroun," ORSTOM, Fond 554 Documentaire No 14525 Cpte B.13, 1986, https://www.documentation.ird.fr/hor/fdi:09986.
[18] Z. P. H. Amvan, L. Biyiti, F. Tchoumbougnang, C. Menut, G. Lamaty, and P. Bouchet, "Chemical composition and antifungal activity of thirteen essential oils from aromatic plants of Cameroon," Flavour and Fragrance Journal, vol. 13, pp. 107-114, 1998.

[19] Y. S. P. Danga, E. N. Nukenine, L. Younoussa, and C. O. Esimone, "Phytochemicals and larvicidal activity of Plectranthus glandulosus (lamiaceae) leaf extracts against Anopheles gambiae, Aedes aegypti and Culex quinquefasciatus," International Journal of Pure and Applied Zoology, vol. 2, pp. 160-170, 2014.

[20] J. P. Tsopmejio, J. Momeni, F. Nkouam Tsopjio et al., "Bioactive secondary metabolites from Plectranthus glandulosus Hook. (Lamiaceae)," Phytochemistry Letters, vol. 30, pp. 133-137, 2019.

[21] A. L. M. Fongang, E. L. Nguemfo, C. B. Zangueu, H. L. Ngando, P. E. K. Belle, and A. B. Dongmo, "Antinociceptive and anti-inflammatory effects of the aqueous leaves extract of Plectranthus glandulosus Hook. F. (Lamiaceae) in mice and rats," Pharmacologia, vol. 7, no. 1, pp. 60-66, 2016.

[22] S. P. Y. Danga, E. N. Nukenine, L. Younoussa, C. Adler, and C. O. Esimone, "Efficacy of Plectranthus glandulosus (lamiaceae) and Callistemon rigidus (myrtaceae) leaf extract fractions to Callosobruchus maculatus (coleoptera: bruchidae)," Journal of Insect Science, vol. 15, no. 1, pp. 601-616, 2015.

[23] A. Goudoum, T. L. S. Ngamo, M. B. Ngassoum, and C. M. Mbofung, "Antioxidant activities of essential oils of Clausena anisate (Rutaceae) and Plectranthus glandulosus (Labiateae), plants used against stored grain insects in North Cameroon," International Journal of Biological and Chemical Sciences, vol. 3, no. 3, pp. 567-577, 2009.

[24] J. Eloff, "A sensitive and quick microplate method to determine the minimal inhibitory concentration of plant extracts for bacteria," Planta Medica, vol. 64, no. 08, pp. 711-713, 1998.

[25] V. Kuete, G. F. Wabo, B. Ngameni et al., "Antimicrobial activity of the methanolic extract, fractions and compounds from the stem bark of Irvingia gabonensis (Ixonanthaceae)," Journal of Ethnopharmacology, vol. 114, no. 1, pp. 54-60, 2007.

[26] W. De-Ekmamkul and B. B. Potduang, "Biosynthesis of betasitosterol and stigmasterol in Croton sublyratus proceeds via a mixed origin of isoprene units," Phytochemistry, vol. 62, pp. 389-393, 2003.

[27] D. Palu, A. Bighelli, J. Casanova, and M. Paoli, "Identification and quantitation of ursolic and oleanolic acids in Ilex aquifolium L. Leaf extracts using 13C and 1H-NMR spectroscopy," Molecules, vol. 24, no. 23, pp. 4413-4427, 2019.

[28] J. N. Alarcon, "Pilloin, a new flavone from ovidia pillo-pillo," Journal of Organic Chemistry, vol. 36, pp. 3829-3830, 1971.

[29] S. Nualkaew, P. Padee, and C. Talubmook, "Hypoglycemic activity in diabetic rats of stigmasterol and sitosterol-3-O$\beta$-D-glucopyranoside isolated from Pseuderanthemum palatiferum (Nees) Radlk. Leaf extract," Journal of Medicinal Plants Research, vol. 9, pp. 629-635, 2015.

[30] P. Younghee, M. Byoung-Ho, Y. Heejung, L. Youngshim, L. Eungjung, and L. Yoongho, "Spectral assignments and reference. Data complete assignments of NMR data of 13 hydroxymethoxyflavones," Magnetic Resonance In Chemistry, vol. 45, pp. 1072-1075, 2007.

[31] N. Saewan, S. Koysomboon, and K. Chantrapromma, "Antityrosinase and anti-cancer activities of flavonoids from Blumea balsamifera DC," Journal of Medicinal Plants Research, vol. 5, pp. 1018-1025, 2011. 
[32] R. Mangoyi, J. Midiwo, and S. Mukanganyama, "Isolation and characterization of an antifungal compound 5-hydroxy-7,4'dimethoxyflavone from Combretum zeyheri," BMC Complementary and Alternative Medicine, vol. 15, pp. 405-416, 2015.

[33] A. Garcia-Granados, A. Martinez, J. Moliz, A. Parra, and F. Rivas, "2-a, 3-b-Dihydroxyolean-12-en-28-oic acid (maslinic acid)," Molecules, vol. 3, no. 8, p. M88, 1998.

[34] S. B. Mahato and A. P. Kundu, "13C NMR Spectra of pentacyclic triterpenoids-a compilation and some salient features," Phytochemistry, vol. 37, no. 6, pp. 1517-1575, 1994.

[35] M. Miski, A. Ulubelen, and T. Mabry, "6-Hydroxyflavones from Thymbra spicata," Phytochemistry, vol. 22, no. 9, pp. 2093-2094, 1983.

[36] E. Tóth, G. Tóth, I. Máthé, and G. Blunden, "Martynoside, forsythoside B, ladanein and 7a-acetoxyroyleanone from Ballota nigra L," Biochemical Systematics and Ecology, vol. 35, no. 12, pp. 894-897, 2007.

[37] H. Kizu and T. Tomimori, "Studies on the constituents of Clematis species. V. On the saponins of the root of Clematis chinensis Osbeck. (5)," Chemical and Pharmaceutical Bulletin, vol. 30, no. 9, pp. 3340-3346, 1982.

[38] H. P. Tchivounda, B. Koudogbo, Y. Besace, and E. Casadevall, "Cylicodiscic acid, a dihydroxy pentacyclic triterpene carylic acid fromCylicodiscus gabunensis," Phytochemistry, vol. 29, no. 10 , pp. $3255-3258,1990$.

[39] K. R. Markham and N. A. Moore, "Comparative flavonoid glycoside biochemistry as a chemotaxonomic tool in the subdivision of the classical "genus" lycopodium," Biochemical Systematics and Ecology, vol. 8, no. 1, pp. 17-20, 1980.

[40] A. Ulubelen, R. Bucker, and T. J. Mabry, "Flavone 5-O-glucosides from daphne sericea," Phytochemistry, vol. 21, no. 3, pp. 801-803, 1982.

[41] C. R. Ji, Y. Z. Liu, W. S. Feng, M. T. Wang, and T. Z. Zhao, "Flavonoids in the yuanhua leaf (Daphne genkwa)," Chinese Traditional and Herbal Drugs, vol. 17, pp. 487-489, 1986.

[42] M. M. Cowan, "Plant products as antimicrobial agents," Clinical Microbiology Reviews, vol. 12, no. 4, pp. 564-582, 1999.

[43] R. Reghu, P. Sahadevan, and S. Sugathan, "Antimicrobial agents from plants," in Bioresources and Bioprocess in Biotechnology, S. Sugathan, N. Pradeep, and S. Abdulhameed, Eds., Springer, Singapore, 2017.

[44] B. Khameneh, M. Iranshahy, V. Soheili, and B. S. F. Bazzaz, "Review on plant antimicrobials: a mechanistic viewpoint," Antimicrobial Resistance \& Infection Control, vol. 8, p. 118, 2019.

[45] J. D. D. Tamokou, A. T. Mbaveng, and V. Kuete, "Antimicrobial activities of African medicinal spices and vegetables, Medicinal Spices and Vegetables from Africa," in Medicinal Spices and Vegetables from Africa, Chapter 8, V. Kuete, Ed., Academic Press, Cambridge, MA, USA, 2017, pp. 207-237.

[46] V. Kuete, "Potential of Cameroonian plants and derived products against microbial infections: a review," Planta Medica, vol. 76, no. 14, pp. 1479-1491, 2010.

[47] J. L. Ríos and M. C. Recio, "Medicinal plants and antimicrobial activity," Journal of Ethnopharmacology, vol. 100, no. 1-2, pp. 80-84, 2005.

[48] M. B. Ngassoum, L. Jirovetz, G. Buchbauer, and W. Fleischhacker, "Investigation of essential oils of Plectranthus glandulosus Hook f. (Lamiaceae) from Cameroon," Journal of Essential Oil Research, vol. 13, no. 2, pp. 3-75, 2001.

[49] P. Bashyal, P. Parajuli, R. P. Pandey, and J. K. Sohng, "Microbial biosynthesis of antibacterial chrysoeriol in recombinant Escherichia coli and bioactivity assessment," Catalysts, vol. 9, no. 2, p. 15, 2019.

[50] J.-M. Pagès and L. Amaral, "Mechanisms of drug efflux and strategies to combat them: challenging the efflux pump of Gram-negative bacteria," Biochimica et Biophysica Acta (BBA)-Proteins and Proteomics, vol. 1794, no. 5, pp. 826-833, 2009.

[51] F. Van Bambeke, J.-M. Pagès, and V. J. Lee, "Inhbitor of bacterial efflux pumps as adjuvants in antibacterial therapy and diagnostic tools for detection of resistance by efflux," Frontier in Anti-infective Drug Discovery, vol. 1, pp. 138-175, 2010. 